\title{
Engrenagens de uma maquinaria repressiva: considerações sobre o Golpe Civil-Militar de 1964
}

The workings of a repressive apparatus: considerations on the 1964 civil-military coup

\author{
Pablo Francisco de Andrade Porfírio* \\ pabloporfirio@hotmail.com
}

Resumo: Este artigo investiga como o Golpe Civil-Militar de 1964 foi vivenciado na Zona da Mata de Pernambuco, centro de atuação dos principais movimentos sociais do período. $\mathrm{O}$ relato de memória do trabalhador aposentado José Sebastião foi tomado como fio condutor desta narrativa. Ele oferece indícios sobre o operativo civil e militar que funcionou naquela região antes e durante o movimento golpista. As informações produzidas pela memória foram cotejadas com outras fontes documentais, como imprensa, relatórios administrativos, processos judiciais e mesmo outros relatos orais. Ao fim, buscou-se apresentar aspectos da maquinaria repressiva em funcionamento na Zona canavieira de Pernambuco no início da década de 1960 e problematizar uma invisibilidade da condição dos trabalhadores rurais como vítimas dos militares a partir de 1964.

Palavras-chave: Golpe civil-militar de 1964, trabalhadores rurais, repressão, Pernambuco

Abstract: This article investigates how the Civil-Military Coup of 1964 was experienced in Pernambuco Forest Zone, operations center of the main social movements of the period. The memory account of the retired worker José Sebastião was taken as a common thread of this narrative. It provides clues about the civil and military operative that worked in that area before and while the coup movement. The information produced by the memory was collated with other documentary sources, such as press releases, reports, processes and even other oral accounts. At the end, it presents aspects of the repressive machinery into operation in the sugarcane area of Pernambuco in the early 1960s and problematize an invisibility of the condition of rural workers as victims of the military since 1964.

Keywords: 1964 civil-military coup, rural workers, repression, Pernambuco

*Professor do Colégio de Aplicação da UFPE e integrante do Projeto Memória e História TRT/UFPE. 


\section{Introdução}

Há algum tempo uma pergunta se faz presente em minhas pesquisas: como o golpe de 31 de março de 1964 foi vivenciado na Zona da Mata canavieira de Pernambuco? Não é uma questão de simples resolução. Contudo, coloco-me o desafio de oferecer ao leitor algumas respostas a partir do enredamento de indícios encontrados na documentação que pesquiso há alguns anos.

Um primeiro ponto a ser destacado é que a ampla historiografia sobre o golpe civil-militar de 1964 pouco se debruçou acerca daquela pergunta ${ }^{1}$. Entendo que, em alguma medida, isso decorre da dificuldade em acessar as fontes documentais sobre a repressão no meio rural. Sabe-se que houve muita violência em 1964, mas não se consegue ainda detalhá-la. Não com o fim de apresentar os horrores de toda forma de violência, mas para entender as estratégias de funcionamento de uma maquinaria que em poucos dias eliminou, matando ou prendendo, as lideranças políticas e os integrantes dos principais movimentos sociais do campo.

Há ainda a ideia de que apesar de o golpe ter sido um levante armado, não foi necessário disparar tiros para derrubar o governo do presidente João Goulart, nem para desarticular os principais movimentos de esquerda. Nesse sentido, para um público mais amplo a violência sistemática do governo militar teria se iniciado a partir de 1968, com o Ato Institucional $n^{\circ} 5$, contra os movimentos de guerrilha urbana e do Araguaia. No que se refere especificamente à zona canavieira de Pernambuco, a análise de que os discursos de Francisco Julião, os quais afirmavam haver milhares de camponeses armados, prontos para resistir, foram considerados bravatas tanto para a direita quanto para parte da esquerda, parece desconsiderar que se não havia camponeses prontos para a resistência armada, houve a execução de um esquema de repressão contra os trabalhadores.

Por fim, deve-se destacar que essa violência repressiva foi exercida por uma aliança entre latifundiários e a força do Estado. Nos primeiros dias de abril, várias lideranças camponesas e trabalhadores rurais foram perseguidos e mortos por milícias privadas dos latifundiários com a garantia, por parte do Estado, da impunidade (CARNEIRO; CIOCCARI, 2011, p. 27; KOURY, 2010, p. 206). Essa aliança foi institucionalizada durante o regime militar e contribuiu para a produção de um silenciamento em relação à condição dos camponeses como vítimas de primeira hora do gol$\mathrm{pe}^{2}$. Nos processos atuais de reparação homologados pelo Governo Federal, poucos são os casos aprovados que envolvam camponeses. A Comissão de Anistia de Mortos e Desaparecidos reconhece um total de 457 vítimas da ditadura, sendo apenas 17 trabalhadores rurais (VIANA, 2013).

Esses aspectos acabam por criar uma invisibilidade para os movimentos do campo e seus atores sociais para o estudo do golpe de 1964. Para enfrentar essa questão, este artigo recorrerá ao relato de memória como fonte principal. Terá como fio condutor da sua narrativa a entrevista concedida por José Sebastião, trabalhador rural dos canaviais em 1964. A partir dela, procura-se oferecer novos indícios sobre a vivência do golpe civil militar na Zona da Mata de Pernambuco e

\footnotetext{
${ }^{1}$ Sobre essa questão devem-se destacar dois trabalhos que nos últimos anos ofereceram uma nova abordagem para a temática camponesa. O primeiro é o livro Retrato da Repressão Política no Campo Brasil 1962-1985: Camponeses torturados, mortos e desaparecidos. Brasília: MDA, 2011. organizado por Marta Cioccari e Ana Carneiro; o outro é o Relatório Final de Violações de Direitos no Campo (1946-1988) elaborado pelos pesquisadores da Comissão Camponesa da Verdade e publicado pela Unb em 2015. As duas publicações afirmam, em linhas gerais, que há um silenciamento sobre a repressão contra os movimentos rurais antes, durante e mesmo depois da ditadura instalada a partir de 1964.

2 Para Carlos Fico, a ditadura irá institucionalizar, por meio dos Atos Institucionais, a repressão já existente. Não se analisa, entretanto, o caso da repressão no campo (FICO, 2001).
} 
relacioná-la com os aspectos suscitados nessa breve introdução, com destaque para a tese da existência de uma aliança operativa entre latifundiários e forças do Estado.

\section{Os trabalhadores}

Em 2014, encontrei com José Sebastião no município de Gameleira, Zona da Mata Sul de Pernambuco. Aos 82 anos, o trabalhador rural aposentado apresentava-se como um bom narrador, emaranhando em seu relato diversos momentos da sua vida e do cenário político do século XX. Parecia já haver praticado algumas vezes o contar de sua vida. Nascido no município de Bonito, Agreste de Pernambuco, o menino José vivenciou o falecimento de sua mãe quando tinha apenas seis anos. Neste tempo, já trabalhava com seu pai, que era um pequeno agricultor. Com sete anos, os desentendimentos com sua madrasta o levaram a sair de casa. Fugiu para a cidade de Gameleira, para a casa de José Martins, também natural de Bonito ${ }^{3}$.

Em sua nova vida, foi levado e apresentado por José Martins ao administrador da Usina Pedroza. Sebastião recordou como teria sido o diálogo:

José Martins, esse menino tá muito pequeno para trabalhar. Ele falou: não, mas esse menino é trabalhador, conheço ele. $O$ cidadão, o administrador virou para mim assim e disse: o que é que você quer fazer? Qualquer serviço que o senhor me der que a minha força dê para eu executar eu vou fazer. Você quer pastorar boi? Ah, para mim foi o mesmo que abrir uma porta no céu, que eu sempre gostei de lidar com animal... quero, senhor. Pronto, você vai pastorar boi. Eu quero ver se você é bom pra pastorar boi. Eu pastorei boi... quatro anos. Com doze anos me botaram para chamar boi no arado $[\ldots]$ com quinze anos eu fui
cambitar. ${ }^{4}$

O relato de memória de José Sebastião primou por selecionar a imagem do trabalhador como marca principal para sua trajetória desde os primeiros anos de vida $^{5}$. Nesse ponto, sua história se aproximava de outras crianças, que empregavam sua força de trabalho nos canaviais de Pernambuco. Esse foi o caso dos irmãos Manoel Francisco Ferreira, Manoel Cordeiro e João Francisco Ferreira, com idades de 13, 12 e 10 anos respectivamente, que em setembro de 1964 recorreram, por meio de sua mãe, Josefa Ferreira da Silva, à Justiça do Trabalho. Os pequenos dedos, que marcaram os espaços destinados às assinaturas dos reclamantes, indicam a fragilidade daquele corpo diante do árduo trabalho nos canaviais e a ausência da formação escolar. Os reclamantes trabalhavam, desde 1963, com seu pai no Engenho Tambô, município de Timbaúba, Zona da Mata Norte de Pernambuco. O genitor faleceu e em seguida os meninos foram demitidos do trabalho, sob a alegação de que não estavam produzindo a contento. Junto com sua mãe, acionaram a Justiça para reclamar o pagamento de $13^{\circ}$ salários, referentes aos anos de 1963/64, indenização, aviso-prévio e férias. O processo foi encerrado por desistência dos reclamantes. Não nos foi oferecido os motivos que levaram a tal opção. Sabese que, assim como José Sebastião, os irmãos Manoel Francisco Ferreira, Manoel Cordeiro e João Francisco Ferreira enfrentavam desde tenra idade as violências do mundo do trabalho. ${ }^{6}$

Sebastião, ao contrário da maioria dos trabalhadores, conseguiu se alfabetizar. No início, juntou

\footnotetext{
${ }^{3}$ As referências a vida de Sebastião foram retiradas da entrevista com ele. Gameleira, 21 de julho de 2014.

4 O Cambiteiro transportava cana no lombo de animais. Trecho da entrevista realizada com José Sebastião em 21 de julho de 2014 , na cidade de Gameleira.

5 Aqui não se deve perder de vista que na narrativa de uma vida, como afirma Daniel James, "em parte os elementos discordantes são, em um sentido formal, subsumidos, reconfigurados segundo o modelo dominante da epopéia romântica". Neste caso, seria a epopéia do trabalhador exemplar (JAMES, 2004, p. 168)

${ }^{6}$ Processo da JCJ de Nazaré da Mata no $742 / 64$. Arquivo TRT/UFPE
} 
um grupo de 12 trabalhadores que se cotizavam para pagar as aulas do senhor Ananias - Cabo geral de engenho que cobrava cinco tostões por semana de cada aluno. Depois, foi estudar no colégio da Usina Pedroza. Ele relembrou o diálogo com o gerente, ocorrido em uma sexta-feira, no meio do canavial, quando conseguiu a autorização para frequentar o colégio:

Vocês querem ir para usina estudar? Toda vida eu fui meio atravessado [risos]... sou eu, doutor. Ele disse: olhe, eu já falei lá no colégio da usina e tem lugares para vocês estudarem. Agora só tá ruim é a condução. Que eu mando o automóvel de linha [linha férrea], mas pega aluno no engenho Pinderal, Jumaitá, aqui onde nós estamos[...], Pitombeira de baixo... para chegar na usina. [...] mas se eu mandar uma carrocinha vocês vão? Eu disse: vamos... todo mundo empolgado[...] Com uns dias um bocado desistiu, né. Não veio doze, veio dez... foi desistindo... eu sei que ficou quatro. $^{7}$

Quando terminou os estudos no colégio, Sebastião e outros quatros alunos tornaram-se empregados da Usina Pedroza. Começaram a praticar com um Cabo até adquirirem experiência para tomar conta de uma turma de trabalhadores. Sebastião recordou que com poucos dias seu instrutor já avaliava que ele estava pronto para exercer a função de Cabo. Esperou, contudo, um mês para chefiar sua própria turma.

Por sua produtividade no trabalho no canavial, seu poder de comando e sua formação escolar, Sebastião lembrou que foi se destacando e ocupando novos cargos nos engenhos e usinas por onde passou, chegando à função de administrador.

\section{As reivindicações}

Ribeirão e Gameleira são municípios vizinhos da Zona da Mata Sul de Pernambuco. Na divisa entre eles situam-se a Usina Estreliana e o Engenho Cachoeira Lisa. A primeira pertencia a José Lopes de Siqueira Santos, que além de usineiro era deputado federal pela UDN e depois pelo PTB. No segundo, José Sebastião trabalhou entre 1956 e 1964 . Nessa região, no início da década de 1960, havia uma forte tensão social provocada pela repressão dos latifundiários à mobilização dos trabalhadores por direitos sociais. Em 07 de janeiro de 1963, um grupo de cortadores de cana de diversos engenhos foi reivindicar o pagamento do $13^{\circ}$ salário atrasado no escritório da Usina Estreliana. Teriam consigo uma carta, assinada pelo Delegado Regional do Trabalho, Enoque Silveira, assegurando o direito de receber aquele salário extra que, à época, também era conhecido com abono de natal ${ }^{8}$. A lei $n^{\circ} 4090$ de 13 de julho de 1962 instituiu o direito dos trabalhadores receberem o pagamento desse benefício. Sebastião rememorou quando the foi pago seu primeiro salário extra, provavelmente no início de 1964

Então, esses dois cidadãos, tanto Gregório [Bezerra] como [Francisco] Julião... olha, vocês vão ter direito a um mês de trabalho no mês de dezembro que se chama abono de natal [...] eu sei que o primeiro décimo que eu recebi a usina pagou uma parte em dinheiro e pagou outra parte em mercadoria que a gente comprava no armazém operário da usina [...] o armazém operário era muito sortido, tinha muita coisa, tinha muita roupa... fazenda, naquele tempo não tinha roupa feita, era fazenda, tinha chapéu, tinha sapato. Eu fui e comprei... o meu sonho era comprar um Ramenzoni $3 x$, um chapéu Ramenzoni $3 x$, que era o chapéu famoso. ${ }^{9}$

\footnotetext{
${ }^{7}$ Entrevista com José Sebastião. Op. Cit.

${ }^{8}$ Esse episódio está narrado na reportagem do Jornal do Commércio. Usina Estreliana: cinco mortos e três feridos num violento conflito ontem, 08 de janeiro de 1963, p. 15. APEJE.

${ }^{9}$ Entrevista com José Sebastião. Op. Cit.
} 
O caráter positivo construído pela memória de Sebastião para o momento de recebimento do seu primeiro $13^{\circ}$ salário, não se repete na trajetória de outros trabalhadores. O grupo que reivindicou esse direito no escritório da Usina Estreliana, em janeiro de 1963, foi duramente reprimido por José Lopes e seus capangas. Cinco trabalhadores foram mortos, alguns desses com tiros de fuzil nas costas, o que caracterizava o assassinato por armas de uso restrito ao exército (PORFÍRIO, 2009, p. 80). Ainda nesse ano, o presidente do Sindicato dos Trabalhadores Rurais de Escada, Marcos Martins da Silva, que realizava uma campanha pelo direito do recebimento do $13^{\circ}$ salário pelos camponeses, foi sequestrado por policiais à paisana. Depois de espancado, foi levado à Usina Caxangá, localizada no município de Ribeirão, pertencente a José Lopes de Siqueira Santos até o final da década de 1950, quando foi vendida a Júlio Maranhão. Em uma entrevista, Marcos Martins relembrou sua prisão na usina: "Me botaram num quarto incomunicável. Toda usina tinha uma cadeia escondida chamada 'Benedita' - um quartinho pequeno, bem fechado, como uma catacumba de defunto, que só tinha um buraquinho para tomar fôlego" (SAUER, 2015, p. 233). Ele conseguiu sair da prisão ao enviar, por uma menina que passou no local, um bilhete ao sindicato, informando onde estava e que iria ser assassinado (SAUER, 2015, p. 233).

Mas retomemos o relato de José Sebastião sobre o pagamento do $13^{\circ}$ salário para inferir sobre alguns pontos. Primeiro, o modo de pagamento do salário extra no Engenho Cachoeira Lisa reproduzia o sistema de barracão, no qual o trabalhador rural recebia parte ou todo seu salário em produtos, por vezes estragados e com preços acima da média, comercializados em vendas (barracões) do próprio engenho. Depois, o direito ao $13^{\circ}$ salário era um dos pontos debatidos nas conversas entre os líderes políticos, como Gregório Bezerra e Francisco Julião, e os camponeses. Essa conscientização dos trabalhadores sobre os seus direitos representava uma ameaça ao poder da oligarquia rural. A resposta dos latifundiários a essa situação se deu em dois níveis no ano de 1963: a intensificação da repressão aos trabalhadores, com milícias privadas agindo junto com policiais após o massacre na Usina Estreliana ${ }^{10}$; e a atuação da Associação dos Fornecedores de Cana de Pernambuco e do Instituto do Açúcar e do Álcool com o objetivo de barganhar vantagens - linhas de crédito - junto ao governo federal. $\mathrm{O}$ assassinato dos trabalhadores em frente ao escritório da usina em Ribeirão foi utilizado para reforçar a urgência da concessão de novos financiamentos, o que, segundo a Associação, acalmaria os trabalhadores e enfraqueceria os agitadores políticos ${ }^{11}$. Essa análise era reproduzida na imprensa. De acordo com reportagem do jornal $O$ Globo, de 11 de janeiro de 1963: "O Banco do Brasil em Pernambuco tomará providências para atender às usinas e engenhos que não tenham conseguido financiamento para o pagamento do 13 (SIC) salário, com o que se tirará aos agitadores o pretexto para as ameaças e tumultos dos últimos dias. "12

Ainda não é possível precisar quando e se esse financiamento chegou. Mas no caso de ter sido criada uma linha de crédito, parece que não foi convertido totalmente para o pagamento dos direitos dos trabalhadores, visto que Sebastião, assim como provavelmente outros trabalhadores, em 1964, foi obrigado a

\footnotetext{
${ }^{10}$ Volantes da PMP vão proteger os engenhos e usinas da Zona Sul. Jornal do Commércio, 10 de janeiro de 1963. p. 03. APEJE; Prontidão da PM pernambucana: cresce a agitação no interior. O Globo, 11 de janeiro de 1963. p. 06. Fundação Biblioteca Nacional.

${ }^{11}$ Essa atuação dos produtores de açúcar e do IAA está descrita na Ata da $1^{\text {a }}$ Sessão 09.1.63. Instituto do Açúcar e do Álcool, Rio de Janeiro, 09 de janeiro de 1963. p. 2. Biblioteca do Instituto Ricardo Brennand.

12 Prontidão da PM pernambucana: cresce a agitação no interior. O Globo, Op. Cit.
} 
receber parte do pagamento de seu $13^{\circ}$ salário em produtos.

Os agitadores citados pelo jornal $O$ Globo não são nomeados na reportagem, mas é possível pensar que se fazia referência a Gregório Bezerra e Francisco Julião. Eles aparecem no início do relato de memória de José Sebastião sobre o recebimento do seu primeiro salário extra. Para ele, em alguma medida, a conquista desse direito estava relacionada com as atuações dos ditos agitadores. O depoimento de Sebastião indicou ainda o seu envolvimento com os principais líderes de esquerda da época. Onde e como ele teria escutado Julião e/ou Gregório falarem sobre o direito ao $13^{\circ}$ salário? Sebastião não nos ofereceu a resposta para essa questão. No entanto, apresentou pistas da sua participação nas Ligas Camponesas.

Começamos com as Ligas Camponesas, fazendo essas reuniões nos engenhos [... ] participava dessas reuniões no engenho Duas Barras e no arruado que tinha ali chamado Arruado do Mateus. A gente tava se reunindo lá, depois a turma da usina descobriu e pegaram a perseguir e vinha de noite, ai a gente ia se reunir numa mata que tinha ali em cima chamada Floresta. Quando a gente chegava limpava a folha num lugar assim e quando a gente saía ciscava a folha todinha assim no lugar e botava um graveto de pau... tinha ponta de cigarro, ai dizia: olhe, quem for fumar bota a ponta de cigarro aqui... botava num canto que era pra não deixar lá para eles não descobrirem que a gente tava se reunindo lá. ${ }^{13}$

O relato de memória nos revelou um pouco do cotidiano da mobilização política dos trabalhadores; a perseguição e as estratégias para despistá-la. Dessa maneira, provavelmente, se reuniram as pessoas que foram reivindicar o pagamento do $13^{\circ}$ salário ao usinei- ro José Lopes. Assim também, criava-se uma rede de compartilhamento das ideias defendidas por líderes, como Francisco Julião e Gregório Bezerra, informavase aos trabalhadores dos seus direitos e os organizava para as mobilizações. Essas pequenas reuniões, rápidas, migrantes entre engenhos, matas e arruados, fortaleciam o sentimento dos latifundiários de que estavam perdendo o controle social e político exercido há muito sobre os canavieiros. Mostrava-se ao trabalhador que esse controle não era natural. Apesar de não deixar claro em sua entrevista, é provável que Sebastião divulgasse nessas reuniões as propostas que escutava dos líderes de esquerda supracitados.

Eu lembro que quando eles começavam a reunião, eles colocavam na nossa cabeça que a gente reivindicasse o nosso direito, não abrisse mão do nosso direito. Quando eles conversavam muito, que aconselhavam até a gente resistir a alguma coisa, os trabalhadores não tinham como resistir, mas eles insinuavam isso, e depois eles tinham um livro que escrevia as pessoas que queriam - eles não obrigavam - eles convidavam, mostravam umas vantagens para as pessoas se filiar no Partido [...] Alguém disse que esse partido que ele convidava para se escrever era o Partido Comunista. Eu sei que teve gente que sofreu mais porque era filiado nesse partido... ${ }^{14}$

O trecho do relato começou citando "eles", referindo-se a Julião e Gregório e conclui referindo-se a "ele", o representante do Partido Comunista. Parece haver uma condensação das memórias sobre várias reuniões, o que faz Sebastião não conseguir rememorar ou não desejar falar dos assuntos abordados com mais detalhes em cada evento. É possível, contudo, identificar duas temáticas tratadas nesses encontros, seja com a participação de Gregório Bezerra ou de Francisco Julião. Uma se referia à luta pelos direitos, como o

\footnotetext{
${ }^{13}$ Entrevista com José Sebastião. Op. Cit.

${ }^{14}$ Entrevista com José Sebastião. Op. Cit.
} 
recebimento do $13^{\circ}$ salário. Outra seria a organização de uma resistência, talvez armada, contra as ações repressivas dos latifundiários em decorrências das reivindicações. A rede de comunicação formada entre os camponeses e a circulação das ideias de que eles deveriam reclamar e lutar por seus direitos, inclusive utilizando armas, provocava a intranquilidade dos patrões. Eles buscavam compartilhar esses sentimentos com toda sociedade por meio de reportagens na imprensa escrita que colocavam Pernambuco na beira do caos social (MONTENEGRO, 2004; PORFÍRIO, 2009). Sebastião foi fundamental para o funcionamento dessa rede de comunicação, pois construía uma ligação entre os líderes e os trabalhadores nos engenhos.

Nesses trechos de seu depoimento, Sebastião deixou emergir, timidamente, outra face da sua múltipla identidade. Além do trabalhador exemplar, do homem que domina as letras, ele foi também um mobilizador dos camponeses antes de 1964.

\section{A repressão}

Após os assassinatos ocorridos na Usina Estreliana e antes da posse de Miguel Arraes - ambos em janeiro de 1963 - iniciou-se uma operação da polícia militar nos engenhos da Mata Sul de Pernambuco, atendendo ao pedido dos proprietários. Salvador Batista do Rêgo, Secretário de Segurança Pública do governo Cid Sampaio, afirmava que a polícia iria atender a todos os donos de engenhos e usinas que estivessem com suas propriedades e vidas ameaçadas. Ainda segundo suas declarações à imprensa, era uma prática legal os usineiros, na qualidade de industriais, armar os seus vigias, formando uma tropa de defesa contra a dilapidação do seu patrimônio. ${ }^{15}$
Proprietários de terras pernambucanos, de acordo com $O$ Globo, visitaram o comandante da $7^{a}$ Região Militar, General Antonio Carlos Murici. Solicitaram garantias do Exército para as suas propriedades e as suas vidas, as quais estariam ameaçadas por integrantes das Ligas Camponesas. Ainda segundo o jornal, o general reconheceu a gravidade do momento, mas informou que o Secretário de Segurança Pública do Estado era quem deveria oferecer as garantias pleiteadas. $^{16}$

Até janeiro de 1963 havia uma relação colaborativa entre latifundiários e forças policiais do Estado de Pernambuco na repressão aos movimentos dos trabalhadores rurais. A partir do mês seguinte, o novo governador - Miguel Arraes - tentou alterar essa relação, determinando que a polícia se posicionasse de modo a mediar os conflitos na Zona da Mata de Pernambuco. Ou seja, não estaria mais à disposição dos interesses particulares de usineiros e donos de engenho como era de costume (CALLADO, 1990; DABAT, 2008).

Apesar do general Antonio Carlos Murici não ter atendido as solicitações dos latifundiários, de acordo com $O$ Globo, sabe-se que esses se armaram e contaram com o apoio das forças repressivas do Estado. Ainda segundo reportagem desse jornal, Fábio Correia, deputado estadual pela UDN e proprietário da usina $\mathrm{Ca}-$ choeira Lisa, vizinha a Estreliana, na madrugada do dia 09 de janeiro, seguiu para suas terras, acompanhado de uma volante da polícia militar de Pernambuco. ${ }^{17}$

José Sebastião relembra que o arsenal existente nas mãos dos proprietários de terra era pesado ${ }^{18}$, composto por revólveres, escopetas e fuzis. Fernando Bar-

\footnotetext{
${ }^{15}$ Volantes da PMP vão proteger os engenhos e usinas da Zona Sul. Jornal do Commércio, Op. Cit.

${ }^{16}$ Prontidão da PM pernambucana: cresce a agitação no interior. Op. Cit.

${ }_{17}^{17}$ Prontidão da PM pernambucana: cresce a agitação no interior. Op. Cit.

${ }^{18}$ Entrevista com José Sebastião. Gameleira, 21 de julho de 2014.
} 
bosa, ex-integrante da juventude comunista do PCB e das Ligas Camponesas, em entrevista ao projeto Marcas da Memória, em 2011, ofereceu um indício de onde vinham essas armas. Durante algum tempo no início da década de 1960, Fernando, então estudante do curso de medicina, serviu ao Exército. Em um determinado dia, estando na Ajudância Geral do IV Exército, em Recife, ouviu um diálogo entre dois militares que debatiam como as armas enviadas para usineiros e senhores de engenho da Mata Sul de Pernambuco retornariam às Forças Armadas. Ele ainda recordou em sua entrevista que a pessoa responsável por receber as armas oriundas do Exército e distribuí-las entre os proprietários da região era José Lopes de Siqueira Santos.

\section{[...] quem tinham as armas eram os usineiros, porque eu estava na Ajudância geral do $4^{\circ}$ Exército em 1961 e vi quando um Coronel, como era o nome dele meu Deus? Eu sei que ele discutia com o Bis- marck e com o Albuquerque, porque que as armas estavam saindo da $7^{a}$ Região Militar para entregar a José Lopes de Siqueira Santos na usina, e José Lopes distribuir com os usineiros da Zona da Mata Sul para combater os Sindicatos Rurais, como é que se ia recolher essas armas? Porque as armas não podiam ser emprestadas, armas privativas das For- ças Armadas, não podiam ser empresta- das a civis. Eu sei que os três oficiais, coronéis estavam discutindo isso, e eu caladinho trocando de roupa, eles não me viram. E eu passei isso para o pes- soal. Eu digo: olhe está acontecendo is- so, eles estão distribuindo armas, e a pessoa que está pegando as armas é a José Lopes de Siqueira Santos. E você vê que em 1964, ele metralhou o pessoal com as armas do Exército na usina, ma- tou um monte de gente. ${ }^{19}$}

No final do trecho acima, Fernando talvez estivesse relembrando o episódio de janeiro de 1963, ocorrido na Usina Estreliana. É possível que a memória confunda algumas datas e por isso é necessário que seja confrontada com outros documentos. Tal lembrança, entretanto, torna cada vez mais visível, juntamente com outros indícios da documentação, a relação entre as ações dos latifundiários e o apoio do exército, conformando uma maquinaria repressiva desde antes do golpe. Sobre 1964, Sebastião recordou que na manhã do dia 02 de abril, ao comandar sua turma de canavieiros no eito, um dos assuntos abordado nas conversas foi o desaparecimento de um trabalhador rural depois de ser preso no dia anterior. Rememorou ainda o debate em torno da notícia da prisão do governador Miguel Arraes, quando se especulava o que poderia ocorrer. Neste momento da conversa, chegou um caminhão do exército. Dele desceu o Cabo Santos. Dirigiu-se ao grupo de trabalhadores e perguntou por Sebastião. É possível pensar que ele era procurado por sua atuação na organização dos camponeses e por frequentar reuniões com Francisco Julião e Gregório Bezerra, apesar dessa conclusão não constar no seu relato. Ao se apresentar ao Cabo Santos, ele foi revistado, preso e levado para Ribeirão. Recordou que dezenas de trabalhadores foram presos e conduzidos em caminhões do exército para um galpão que ele acreditava ser do Serviço Social da Indústria - SESI, localizado no centro da cidade de Ribeirão. Muitos choravam, outros tremiam todo o corpo. ${ }^{20}$

Em algum momento desse trajeto, encontrou com um vereador de Ribeirão, que se comprometeu a ajudálo, levando seu caso ao conhecimento do senhor Clóvis, engenheiro com quem Sebastião havia trabalhado. Enquanto esperava uma possível ajuda, iniciaram-se os interrogatórios no SESI. Sebastião foi levado para uma

\footnotetext{
${ }^{19}$ Fernando Barbosa. Depoimento concedido ao projeto "Marcas da Memória: História Oral da Anistia no Brasil” (Equipe da UFPE). Recife, 18/10/2011. pp. 18-19.

${ }^{20}$ Informações retiradas da entrevista com José Sebastião. Op. Cit.
} 
sala, onde estava, segundo sua memória, o Coronel do Exército. $^{21}$

“O senhor é integrante do Partido Comunista?", perguntou-lhe o militar. A resposta foi negativa. Mas o Coronel do Exército parecia ter uma prova que a contradizia. Apresentou um livro do Partido Comunista apreendido com Gregório Bezerra ${ }^{22}$. O líder comunista havia sido preso naquele dia no município de Cortês, próximo a Ribeirão, pelo Capitão Guerreiro da Polícia Militar de Pernambuco, sob ordens do novo Secretário de Segurança Pública do Estado, Coronel Ivan Rui. ${ }^{23}$

Gregório estava sendo conduzido pelos policiais para Recife, quando ao passarem por Ribeirão, no cruzamento da estrada de ferro, encontraram a vanguarda de um destacamento do $20^{\circ}$ Batalhão de Caçadores de Alagoas $^{24}$. De acordo com o comunista, o usineiro José Lopes e seus pistoleiros estavam juntos com o destacamento militar. "Quando o jipe parou, fiquei cercado de soldados que gritavam: 'atira, mata logo este bandido, atira" ${ }^{25}$. Após uma conversa entre o Capitão Guerreiro e José Lopes, ficou decidido que o preso político seria encaminhado para Ribeirão, onde estava acampado o $20^{\circ}$ B.C. O usineiro continuava pedindo o trucidamento do líder comunista. Uma hora depois, contudo, segundo Gregório Bezerra, ele foi amarrado "como um fardo", colocado dentro do caminhão e levado, sob escolta de um pelotão do $20^{\circ} \mathrm{BC}$, para ser apresentado ao comandante do IV Exército, Justino Alves Bastos.

O livro do Partido Comunista, que estaria com Gregório no momento da sua prisão, teria sido então enviado para Ribeirão e utilizado como prova para in- criminar camponeses, como Sebastião que viu assim sua situação se complicar. Paralelo a tudo isso, o engenheiro Clóvis, avisado da prisão de Sebastião, foi procurar sua tia, conhecida como Dona Nána. Apresentou a condição do trabalhador e pediu para que ela intercedesse pela sua soltura. Dona Nána era esposa de José Lopes de Siqueira Santos. $^{26}$

Pode-se ter como hipótese que a atuação do IV Exército no golpe de 1964 esteve mais alinhada aos reclamos e interesses do grupo de latifundiários - alinhamento existente desde antes, como no caso do assassinato de trabalhadores na Usina Estreliana - do que, propriamente, a um plano executado em conjunto com os outros Comandos do Exército. Angela de Castro Gomes e Jorge Ferreira (2014, p. 337) afirmam que não havia, por ocasião do golpe de 1964, uma estratégia que direcionasse as ações de todos os comandos militares. Em entrevista publicada no livro Visões do golpe: a memória militar de 1964, o Coronel Carlos de Meira Mattos reforçou essa interpretação ao relembrar que "a conspiração que acabou na Revolução de 31 de março de 1964 foi uma conspiração multipolar. Houve vários pólos de conspiração e esses pólos não tinham muito entendimento. Não havia um líder revolucionário, nem um chefe revolucionário" (D’ARAUJO; SOARES;CASTRO, 1994, p. 102). O historiador Carlos Fico (2008, p. 76) afirma também que a “conspiração que levou ao golpe foi bastante desarticulada até bem perto do dia 31 de março". Fico, entretanto, constrói uma distinção entre a "campanha de desestabilização" ao governo João Goulart e a "conspiração" que tratou da sua

\footnotetext{
${ }^{21}$ Informações retiradas da entrevista com José Sebastião. Op. Cit.

${ }^{22}$ Informações retiradas da entrevista com José Sebastião. Op. CIt.

${ }^{23}$ As informações sobre a prisão de Gregório Bezerra constam em seu depoimento para o processo no 88/64, no qual era réu. Mércia Albuquerque foi sua advogada de defesa e uma cópia desse processo está no seu arquivo pessoal. A documentação da advogada de outros presos políticos, composta por peças jurídicas, cartas, fotos e outros está sob a guarda da ONG DHNET na cidade de Natal, Rio Grande do Norte. A parte do processo utilizada neste artigo me foi repassada pelo historiador Tasso Brito autor da dissertação A Toga e a Espada: Mércia Albuquerque e Gregório Bezerra na Justiça Militar (1964-1969), defendida no PPGH-UFPE, 2015. Neste trabalho ainda é possível ler sobre a prisão de Gregório nas páginas 51 a 54.

${ }^{24} \mathrm{O} 20^{\circ}$ Batalhão de Caçadores de Maceió atualmente é o $59^{\circ}$ Batalhão de Infantaria Motorizado Hermes Ernesto da Fonseca.

${ }^{25}$ Depoimento de Gregório Bezerra no processo $\mathrm{n}^{\circ}$ 88/64.

${ }^{26}$ Informações retiradas da entrevista com José Sebastião. Op. Cit.
} 
derrubada. Tal análise debate com a tese de René Armand Dreifuss (2006) para quem o processo de desestabilização, iniciado em 1961, intensificado em 1963 e financiado principalmente pelo IPES e IBAD, provocou quase naturalmente a derrubada do governo. Para Carlos Fico, a desestabilização poderia ter promovido a escolha de outro caminho, como o enfraquecimento eleitoral de Jango para as eleições de 1965. Logo, não havia um determinismo entre aqueles dois momentos, apesar de estarem estreitamente relacionados. Além disso, no primeiro momento não ocorreu uma participação intensiva dos militares, estando o planejamento e o financiamento das ações a cargo dos civis. No segundo momento, a atuação dos militares foi destacada, mas se deu modo desorganizado, muitas vezes sem o conhecimento dos principais líderes e com desdobramentos fortuitos (FICO, 2008, p. 76).

José Lopes de Siqueira Santos foi um dos principais atores do golpe civil-militar de 1964 em Pernambuco e do período imediatamente anterior, como na repressão aos trabalhadores em janeiro de 1963. Os relatos de memória Fernando Barbosa, José Sebastião e o depoimento de Gregório Bezerra indicam uma atuação conjunta dele com o exército, seja com setores do IV Exército em Pernambuco, seja com o $20^{\circ}$ Batalhão de Cavalaria de Alagoas $^{27}$, instalado em Ribeirão, sede política do usineiro, utilizando a estrutura da cidade e do Serviço Social da Indústria - SESI.

Essa relação reforça a tese, já bastante debatida, do protagonismo civil, além do militar, na execução do golpe. Há ainda que pensar como ocorreu. Não havia, de acordo com o que citamos anteriormente, uma estratégia única que direcionasse as ações de todos os comandos militares do país por ocasião do golpe de 1964 .
Alguns apoiaram o levante iniciado em Minas Gerais na primeira hora, outros, como o II Exército, liderado pelo general Amaury Kruel, tardaram até as primeiras horas do dia $1^{\circ}$ para definir uma posição oficial (FERREIRA; CASTRO, 2014, p. 337). No caso do IV Exército, a prisão do governador Miguel Arraes durante o $1^{\mathrm{o}}$ de abril revelava seu posicionamento de apoio. Mas a mobilização das tropas na zona canavieira ocorreu antes mesmo da prisão do governador. Socorro Ferraz, estudante e integrante da Juventude Comunista à época, estava na Mata Sul de Pernambuco quando soube do início da movimentação golpista. Realizava atividade de militância para a organização dos trabalhadores rurais. Sobre esse momento, ela recorda:

Quando nós chegamos em Palmares, chovia, era uma chuva fina [...] isso era dia $1^{a}$, a cidade estava completamente deserta, era como uma cidade da guerra e não havia uma pessoa na rua, absolutamente [...] Quando nós chegamos o Exército já vinha entrando na cidade por Alagoas. Mas, olha! Pense num Exército assim, tipo passo de ganso, assim, pá, pá, na cidade, mas foi uma coisa, um impacto, porque a gente sempre um pouco improvisado, a gente sempre achou que as nossas forças, o Exército brasileiro, não era algo tão organizado, mas pense numa coisa violenta. Mas assim, nós ficamos escondidos atrás do posto, nesse jipe, eles não nos viram, passaram, e dai a gente foi até a liga Limão que era nos engenhos. Quando nós chegamos lá, todas as casas estavam fechadas, não havia ninguém nas casas, os camponeses já haviam sido presos, a família já tinha toda debandado para dentro dos matos [...] os camponeses foram presos da noite do dia 31 para o dia $1^{\circ}$ e eles já fizeram todas as prisões, enquanto estavam dizendo a Arraes que ainda iam ver, ia acontecer, eles já estavam prendendo a liderança toda, entendeu? E dai a gente voltou, não tinha mais nada o que fazer, de pessoas para ver, para organizar. ${ }^{28}$

\footnotetext{
${ }^{27}$ Reportagem do Diário de Pernambuco - Polícia vasculha ninhos de agitação, levando ao xadrez líderes comunistas - do dia 03 de abril de 1964 , $\mathrm{p}$. 07, cita a atuação do $20^{\circ}$ Batalhão de Cavalaria de Alagoas na cidade de Ribeirão. O texto, contudo, não faz referência a José Lopes.

${ }^{28}$ Socorro Ferraz. Depoimento concedido ao projeto "Marcas da Memória: História Oral da Anistia no Brasil”. Recife, 29/04/2011. 4ª sessão. p. 28-29.
} 
Os soldados, a quem se refere Socorro Ferraz, eram os integrantes do $20^{\circ}$ Batalhão de Cavalaria. Eles avançaram pela divisa entre Alagoas e Pernambuco, passando por Palmares e se instalado na cidade situada alguns quilômetros depois, Ribeirão. O principal objetivo era atuar na repressão às organizações políticas dos camponeses. É interessante saber que no dia 3 de abril, o governador de Alagoas, Luiz Cavalcanti, veio a Recife para receber uma homenagem por sua atuação durante o golpe. Afirmava o Diário de Pernambuco que ele havia sido um dos primeiros chefes de executivos estaduais a manifestar solidariedade à Revolução. Sua atuação ocorreu em estreito contato com o comando do IV Exército ${ }^{29}$, o que, é possível inferir, facilitou e viabilizou o envio de tropas do $20^{\circ} \mathrm{BC}$ para a Mata Sul de Pernambuco.

Os relatos de memória de Socorro Ferraz, de José Sebastião e mesmo as reações dos proprietários de terra noticiadas na imprensa após o caso da Usina Estreliana indicam que os trabalhadores rurais e seus movimentos sociais foram colocados na condição dos inimigos a serem combatidos pela sociedade. Para tanto se estruturou, de acordo com o relato de Fernando Barbosa, desde antes de 31 de março de 1964, uma ação conjunta entre latifundiários e setores do Exército e o golpe se materializou, na Zona da Mata, como parte de um projeto da oligarquia rural menos contra Jango e mais contra os movimentos sociais e políticos gestados entre os camponeses, questionadores da estrutura agrária no país e reivindicadores dos direitos sociais. A impossibilidade de acesso à documentação do IV Exército é, talvez, o principal fator que não permite a apresentação mais detalhada dessa linha interpretativa. Contudo, não entendo que isso a impossibilite de ser explorada por outros caminhos investigativos. Nesse caso, por meio, principalmente, da memória e das fontes de imprensa. No caso de Pernambuco, latifundiários como José Lopes e instituições como a Associação de Plantadores de Cana de Açúcar estiveram à frente da execução do golpe. Criminalizavam movimentos rurais, como as Ligas Camponesas, através da imprensa, identificando os trabalhadores como um perigo à soberania nacional, associando-os ao processo de cubanização, que exigiria a intervenção das Forças Armadas.

Nesse artigo, defendo o argumento de que no Nordeste e especialmente em Pernambuco, centro do movimento camponês, mesmo não havendo um plano previamente definido para ser executado a partir de 31 de março, existia uma atuação conjunta entre latifundiários e setores do Exército que acabou por direcionar as ações golpistas. Essa ação ocorria desde o período da chamada "campanha da desestabilização", definido por Carlos Fico. E ao contrário dos outros Estados, onde o movimento de 31 de março - ou a "conspiração" - apresentou uma liderança predominantemente de militares, na Zona da Mata Sul de Pernambuco, o usineiro José Lopes a dividia com os militares.

Quando Socorro Ferraz relembra que o Exército marchava sobre Palmares e os camponeses já haviam desaparecido, pode-se pensar que a primeira repressão a Liga Limão, a maior naquela região, tenha sido realizada pelas milícias dos proprietários de terras, municiada por armas das Forças Armadas distribuídas na região por José Lopes de Siqueira Santos.

Ainda em sua entrevista para o projeto Marcas da Memória, em 2011, Fernando Barbosa relembrou:

Pena! Com tudo isso de 1964, matou a nossa liderança camponesa toda. $O$ que foi encontrado de cadáveres, de corpos na estrada entre Caruaru e Campina Grande, inclusive mutilados para ning-

${ }^{29}$ Diário de Pernambuco. Governador alagoano hoje no Recife: receberá homenagem. 04 de abril de 1964. p. 05. 
uém conhecer quem era [...] pouca gente sobrou daquele tempo no campo, pouquíssima gente. Sobrou quem a gente escondeu, uma parte, uns que resistiram porque eram fortes, como Joaquim Camilo, que eu te falei, mas Zé Eduardo e Jessino tiveram que se ausentar, mas o resto... Manoelzinho sumiu, ninguém sabe aonde foi que acabou Manoelzinho. Ele era aqui da Mirueira, trabalhava aqui nesse Litoral Norte todo; Igarassu, Goiana, Paulista. ${ }^{30}$

A memória de Fernando foi marcada pela imagem da intensa violência durante o golpe de 1964. Prisões, torturas e assassinatos de trabalhadores rurais realizados por capangas nos dias do golpe, sob omissão ou apoio do Exército, não foram registrados oficialmente como parte da repressão do golpe e da ditadura que o seguiu. Como citei no início desse artigo, a Comissão de Anistia de Mortos e Desaparecidos reconhece apenas 17 camponeses como vítimas do regime de exceção instalado a partir de 1964 no Brasil (VIANA, 2013).

Nesse caso, parcela de camponeses assassinados, presos e torturados por milícias rurais não tiveram direito à condição de vítimas dos agentes de Estado e, por conseguinte, à indenização. Além disso, tal fato dificulta a formação de uma linha de pesquisa que tome o trabalhador rural como perseguidos políticos da associação entre latifundiários e Forças Armadas em 1964 e mesmo um pouco antes. Dificulta, propriamente, tomarmos essa associação como uma questão a ser pesquisada e analisada no estudo do golpe.

\section{O desfecho}

José Sebastião seguia em uma sala do SESI na cidade de Ribeirão. O Coronel continuava inquirindo sobre o envolvimento do trabalhador com o Partido Comunista:

O coronel lá me investigou. Você se inscreveu no partido de Gregório, foi? Eu disse: não senhor. Eu não me inscrevi não. Mas ele lhe convidou alguma vez? Eu disse: convidou. O senhor assinou alguma folha no livro dele? Eu disse: não assinei. Mas aqui tem seu nome no livro dele. Eu fui e disse: Coronel, eu queria fazer um pedido ao senhor. Pois não, pode fazer. Eu queria ver a assinatura. Ele disse: aqui não tem assinatura não. A pessoa botou o dedo. Ah, Coronel! Eu sei escrever e não boto o dedo em canto nenhum. Para mim, a minha fraca letra é muito na minha vida. Mas você tem conhecimento de outra pessoa nesse engenho duas barras com o mesmo nome seu? Eu disse: tenho. Tem dois lá com o meu mesmo nome, um é tratorista do engenho e o outro é trabalhador do pesado. Então deve ser um desses... e chamou o Cabo Santos e disse: você vai no engenho Duas Barras e você vai me trazer dois José Sebastião da Silva que tem lá [...] e eles moram no engenho? Eu disse: moram. $O$ tratorista mora numa casa perto da usina e o outro mora na rua no bairro chamado Francisco Pinto. ${ }^{31}$

Ao fim, José Sebastião foi libertado. Não é possível precisar por qual motivo e essa não é uma das perguntas desse texto. Interessa-nos, contudo, destacar que na sua trajetória, produzida por meio do seu relato de memória, a sua liberdade pode ser relacionada às suas ações anteriores. A busca pelos estudos, desde as aulas com o senhor Ananias, o que possibilitou ter sua "fraca letra", fator fundamental para se distinguir do homônimo que colocou o dedo no lugar da assinatura no livro do Partido Comunista. Sua condição de trabalhador eficiente - formadora de sua identidade desde a infância, quando foi apresentado ao administrador da Usina Pedroza - teria mobilizado pessoas, como o engenheiro Clóvis, para que intercedessem pela sua

\footnotetext{
${ }^{30}$ Fernando Barbosa. Depoimento concedido ao projeto "Marcas da Memória: História Oral da Anistia no Brasil”. Recife, 18/10/2011. p. 18-19.

${ }^{31}$ Entrevista com José Sebastião. Op. Cit.
} 
liberdade. Neste caso, segundo a memória de José Sebastião, o engenheiro falou com Dona Nána, que deve ter tratado o assunto com seu esposo, José Lopes de Siqueira Santos. É possível conjecturar que sua liberdade resultaria diretamente da ação do usineiro. $\mathrm{Ou}$ ainda que nenhuma dessas hipóteses esteja correta e o trabalhador tenha sido liberado pelo Coronel após algum dos outros trabalhadores homônimos, indicado por Sebastião em seu interrogatório, assumir a inscrição no livro do Partido Comunista.

A trajetória de José Sebastião cruzou com o movimento de repressão aos trabalhadores rurais em 1964. Por algum dos fatores citados ou pela conjunção deles, Sebastião escapou das torturas e mesmo da morte. Por meio de seu relato de vida e das informações de outras fontes documentais, é possível iluminar algumas engrenagens de uma maquinaria que reprimiu duramente os trabalhadores rurais; contribuiu para instituir um regime de exceção no país; institucionalizou o lugar social do crime e do criminoso para os trabalhadores rurais e suas reivindicações por direitos e cidadania, mantendo a concentração de terra no país um tema proibido ao debate.

Saber o desfecho da história de Sebastião durante o golpe de 1964 nos obriga a perguntar sobre o que aconteceu com os integrantes da Liga Camponesa do Engenho Limão na cidade de Palmares e os camponeses presos no SESI da cidade de Ribeirão. Foram muito mais do que 17 trabalhadores rurais.

\section{Referência bibliográfica}

BRITO, Tasso. A Toga e a Espada: Mércia Albuquerque e Gregório Bezerra na Justiça Militar (1964-1969). Dissertação de Mestrado em História defendida no PPGH-UFPE, Recife, 2015.

CALlADO, Antonio. Tempo de Arraes. A revolução sem violência. Ed. Paz e Terra. Rio de Janeiro, 1990.

CARNEIRO, Ana; CIOCCARI, Marta. Retrato da repressão política no campo - Brasil 1962-1985 - Camponeses torturados, mortos e desaparecidos. Brasília: MDA, 2010.

D’ARAUJO, Maria Celina; SOARES, Gláucio; CASTRO, Celso. Visões do golpe: a memória militar de 1964. Rio de Janeiro: Relumé-Dumará, 1994.

DABAT, Christine Rufino. Uma caminhada penosa: a extensão do Direito trabalhista à zona canavieira de Pernambuco. In Revista Clio Clio - Série Revista de Pesquisa Histórica - N. 26-2. Recife. Editora Universitária da UFPE. 2008.

DREIFUSS, René Armand. 1964: a conquista do Estado: ação política, poder e golpe de classe. $6^{\text {a }}$ ed. Petrópolis, Rio de Janeiro: Vozes, 2006.

FERREIRA, Jorge; GOMES, Angela de Castro. 1964: o golpe que derrubou um presidente, pôs fim ao regime democrático e instituiu a ditadura no Brasil. $1^{\text {a }}$ ed. Rio de Janeiro: Civilização Brasileira, 2014

FICO, Carlos. O Grande Irmão: da Operação Brother Sam ao Anos de Chumbo. $2^{\mathrm{a}}$ ed. Rio de Janeiro: Civilização Brasileira, 2008.

FICO, Carlos. Como eles agiam. Os subterrâneos da Ditadura Militar: espionagem e polícia política. Rio de Janeiro: Record, 2001.

FIGUEIREDO, Lucas. Lugar Nenhum: militares e civis na ocultação dos documentos da ditadura. Coleção Arquivos da Repressão no Brasil. São Paulo: Cia. das Letras, 2015. 
JAMES, Daniel. Doña María: historia de vida, memoria e identidad política. 1a ed. Buenos Aires: Manantial, 2004.

KOURY, Mauro Guilherme Pinheiro. Práticas instituintes e experiências autoritárias: o sindicalismo rural na mata pernambucana. Doutorado em Sociologia. Universidade Federal de São Carlos, São Carlos/SP,2010.

MONTENEGRO, Antonio. Labirinto do Medo: O Comunismo (1950 - 1964). CLIO. Série História do Nordeste (UFPE), v. 22, p. 215-235, 2004

PAGE, Joseph A. A revolução que nunca houve: o Nordeste do Brasil. 1955 - 1964. Rio de Janeiro: Ed. Record, 1972.

PORFIRIO, Pablo F. de A. Medo, comunismo e revolução: Pernambuco (1959-1964). Recife: Ed. da UFPE, 2009.

SAUER, Sergio (et. al.) Organizadores. Comissão Camponesa da Verdade. Relatório Final: Violações de Direitos no Campo (1946-1988). Brasília. Dex-Unb, 2015.

VIANA, Gilney. Camponeses Mortos e Desaparecidos: Excluídos da Justiça de Transição. Brasília: Secretaria de Direitos Humanos da Presidência da República. 2013. 